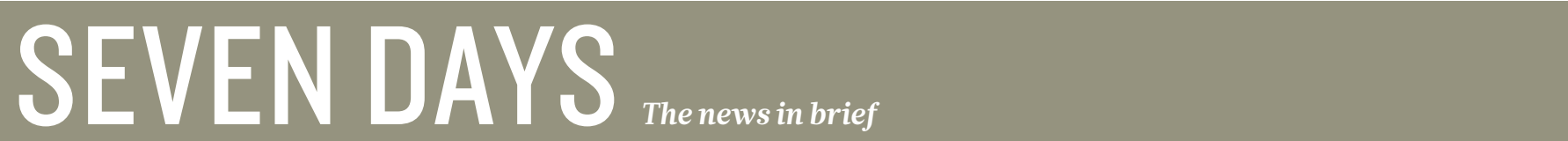

ENERGY

\section{Pipeline challenge}

An influential coalition of environmental groups is challenging in court the US government's decision in March to grant a permit for the controversial Keystone XL pipeline, which would enable the shipment of oil from Canada's oil sands to refineries along the Gulf of Mexico. The lawsuit, led by the Natural Resources Defense Council and filed in a federal court on 30 March, argues that the Department of State arbitrarily reversed its 2015 decision to block the pipeline, announced by former president Barack Obama. It also calls the agency's 2015 environmental assessment of the project outdated and incomplete, arguing that the Trump administration must now update the analysis.

\section{POLICY}

\section{Brazil budget}

The Brazilian government announced a $44 \%$ cut to the 2017 federal science budget on $30 \mathrm{March}$, in response to the country's economic recession and escalating fiscal deficit. The drop in public science spending, part of a general 42-billion-real

\section{NUMBER CRUNCH}

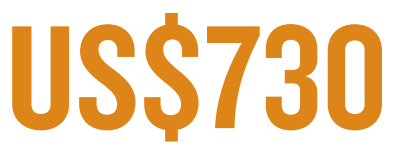

The cost in February of one kilogram of raw ivory in China, down from $\$ 2,100$ in early 2014. The price crash comes as the country prepares to ban its legal ivory trade this year, as part of efforts to stem poaching in Africa.

Source: Save the Elephants

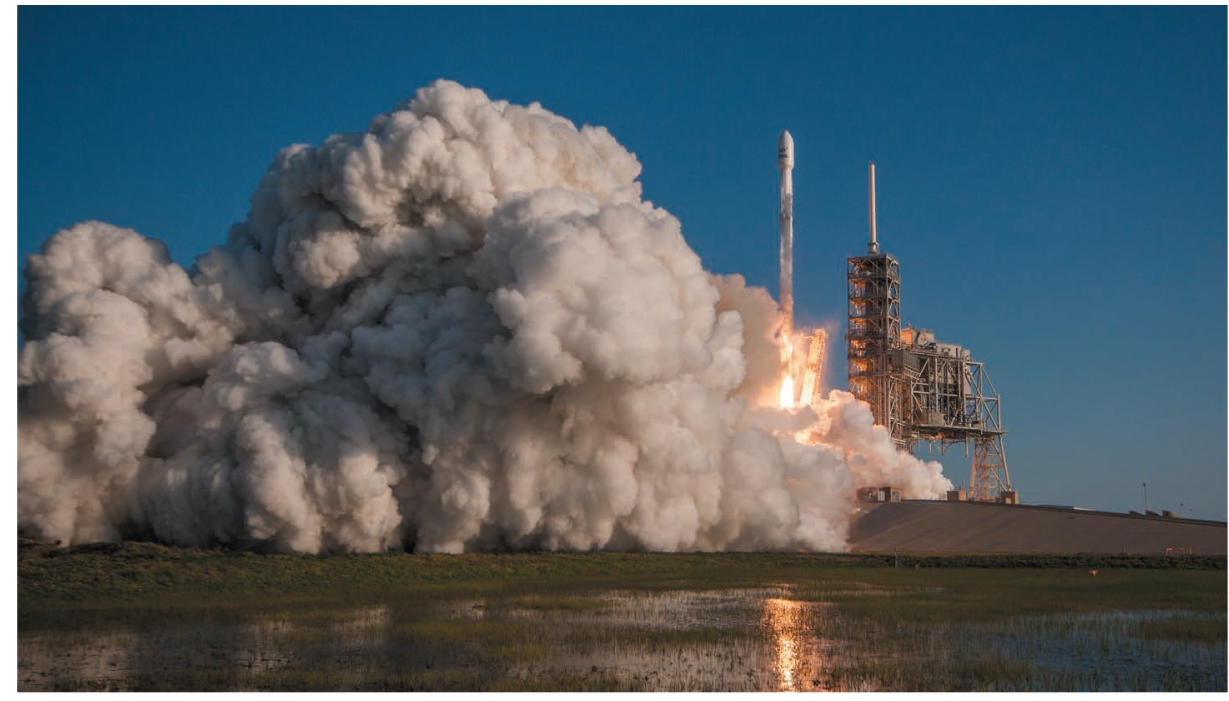

\section{Recycled rocket boosts space flight}

Reusable rocketry took a step forward on 30 March when SpaceX of Hawthorne, California, launched a telecommunications satellite using part of a previously flown Falcon 9 rocket. It is the first time that major components of a rocket have been reused - in this case, the first stage, which provides the bulk of the lift to orbit. The Falcon 9's first stage had been used in an April 2016 launch, and was again recovered after the latest launch from NASA's Kennedy Space Center in Florida.
(US\$13.5-billion) cutback of Brazil's 2017 federal budget, will leave the Ministry of Science, Technology, Innovations and Communications with its sparsest funding in more than a decade. Brazilian scientists and research organizations warn that the drastic cuts to already tight budgets might harm the nation's science for decades to come. See go.nature. com/2nwruji for more.

\section{Embryo research}

Germany's national science academy, the Leopoldina, has called for a loosening of the country's ultrastrict laws on human-embryo research. The law prohibits the use of human embryos and embryonic stem cells in basic research, and bans collaborations with scientists doing such work in countries where it is legal. Violations carry a penalty of up to five years' imprisonment. On 29 March, the Leopoldina said that Germany should follow the United Kingdom, France and Sweden in allowing research on unused embryos from in vitro fertilization for up to 14 days after fertilization - but should restrict studies to non-viable embryos. New gene-editing and sequencing technologies used in combination with such research will help to uncover ways to treat or avoid serious hereditary diseases, it says. See page 25 for more.

\section{Negative truths}

Journals and scientists should treat negative results as valid findings worthy of publication, according to a revised version of a European code of research integrity. The mention of negative results is a new addition to the code, created in 2011 by the All European Academies in Berlin, a network of academic organizations. The European Union's Horizon 2020 programme will cite the document as an example of standards by which its grant recipients must abide.

\section{Turkish-journal call}

Turkey's research agency TÜBİTAK has told journals to remove from their editorial and review boards any academics who have been dismissed or suspended from their institutions in political purges following last July's failed military coup. The move applies to titles listed by TÜBİTAK's publishing unit ULAKBİM. More than 7,300 academics have been dismissed for suspected ties 
to the Gulenist movement, which the government says was responsible for the attempted coup. But many of them are instead widely considered to be opponents of Turkey's president, Recep Tayyip Erdoğan. A 29 March government decree returned just 688 purged academics, around half of them graduate assistants, to their positions.

\section{BUSINESS}

\section{Deep learning}

Google is increasing its stake in artificial intelligence (AI), funding two new projects in Toronto, Canada. The technology giant announced on 30 March that it will contribute US $\$ 5$ million to the Vector Institute, a nonprofit centre affiliated with the University of Toronto that will focus on AI and deep learning. The institute's chief science adviser, computer scientist Geoffrey Hinton, will also be conducting research on deep learning and artificial neural networks at the newly launched Google Brain Toronto, the latest satellite campus of the Google Brain project.

\section{PEOPLE}

\section{Nobel physicist dies}

Physicist Alexei Abrikosov (pictured), who shared the 2003 Nobel Prize in Physics for

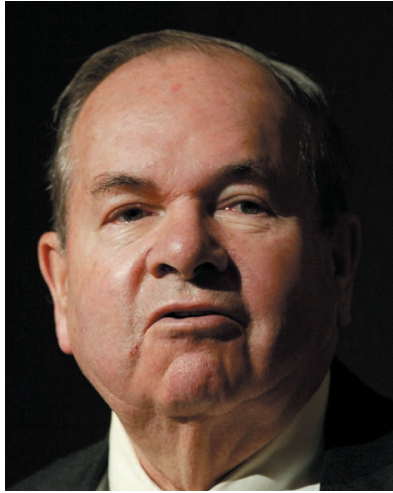

his work on superconducting materials, has died, aged 88 . The Russian physicist, who joined Argonne National Laboratory in Illinois in 1991, had in the 1950s developed a theory of superconductivity in the presence of magnetic fields. He helped to develop 'type II' superconductors, which are used in magnetic resonance imaging and particle accelerators.

\section{ENVIRONMENT}

\section{Pesticide reversal}

In a policy U-turn, the US Environmental Protection Agency (EPA) will now allow a common pesticide, chlorpyrifos, to remain on the market while research on its safety continues. The EPA had proposed a ban on chlorpyrifos in October 2015, and was under a court order to issue a decision by 31 March. On 29 March, EPA administrator
Scott Pruitt rejected the agency's earlier conclusion that the chemical could affect human cognition, particularly among farm workers and children. "We are returning to using sound science in decision-making - rather than predetermined results," Pruitt said.

\section{FACILITIES}

\section{Floral collection}

London's Royal Botanic Gardens, Kew, has launched an online portal that is to include information on all of the world's known seedbearing plants by 2020 . The Plants of the World Online project currently includes entries on African plants, orchids, grasses and palms, adding up to around $27 \%$ of the world's 391,000 vascular plants, drawn from Kew's extensive herbarium and fungarium collections. Kew hopes eventually to have online names, descriptions, ranges and other data - such as correspondence from its archives - from its collections of 200,000 slides, 100,000 living plants and 2 billion seed samples.

\section{HEALTH}

\section{Malaria guidelines}

The World Health Organization (WHO) has released an update of its

\section{TREND WATCH}

The number of annual deaths in children under 19 roughly halved globally between 1990 and 2015 , falling from 14.2 million to 7.3 million. Massive progress has been made in cutting deaths from malnutrition and communicable diseases in children under 5 , but improvements are less dramatic in newborns, according to the study, published in JAMA Pediatrics on 3 April. Progress also varied by region, says the report, which analysed data from 195 countries: most deaths occurred in south Asia and sub-Saharan Africa.

\section{CHILD DEATHS HALVED}

The annual number of under 19s dying globally has fallen over 25 years, but the rates of improvement vary by cause of death.

\section{$1990 \quad 2015$}

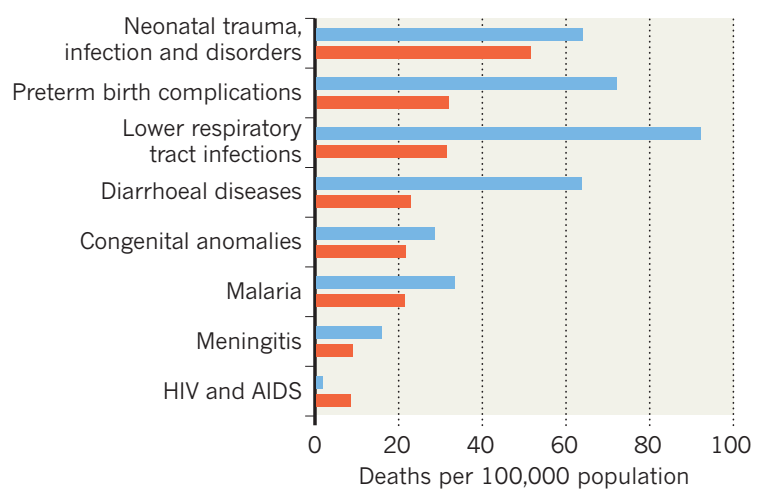

2007 guidelines on malaria elimination. Whereas that report focused on countries that were approaching disease elimination, the latest guidance provides advice for all nations in which malaria is endemic. Among recommended strategies for countries that have high transmission, the WHO now lists mass drug administration - intake of malaria drugs as a preventative measure - as a way to curb the mosquitoborne disease in certain regions. In countries with very low transmission, the agency advises that cases detected through rapid diagnostic tests be confirmed by microscopy.

\section{Mars landing sites}

The European Space Agency announced two possible landing sites for its first Mars rover mission, ExoMars 2020 , on 28 March. The joint mission with Russia will land at either Oxia Planum or Mawrth Vallis. Both sites are vast plains in the planet's northern hemisphere; satellite data suggest they are made of clay that would once have been full of water, and possibly favourable to life. Mawrth Vallis lies at a higher latitude and had previously been deemed unsuitable because of engineering constraints. It was reconsidered after the mission was delayed from 2018 to 2020 , which changed the craft's ultimate angle of approach. The final site will be picked in 2019 .

\section{CLARIFICATION}

The Seven Days item 'GM impasse' (Nature 543,

594; 2017) neglected to mention that the European Commission will now decide on whether to authorize the GM maize varieties.

\section{$\rightarrow$ NATURE.COM}

For daily news updates see:

www.nature.com/news 